\title{
THE EFFECTS OF PURE MICROCYSTIN LR AND BIOMASS OF BLUE-GREEN ALGAE ON SELECTED IMMUNOLOGICAL INDICES OF CARP (Cyprinus carpio L.) AND SILVER CARP (Hypophthalmichthys molitrix Val.)
}

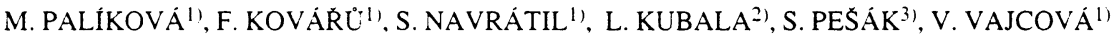 \\ 1) University of Veterinary and Pharmaceutical Sciences, Brno, ${ }^{2)}$ Institute of Biophysics, \\ Academy of Science of Czech Republic. Brno, ${ }^{3)}$ Institute of Clinical Immunology \\ and Allergology of Masaryk University, Brno, Czech Republic
}

Received July 22, 1998

Accepted September 21, 1998

\begin{abstract}
Palíková. M., F. Kovářủ. S. Navrátil. L. Kubala, S. Pešák., V. Vajcová: The Effect of Pure Microcystin LR and Biomass of Blue-green Algae on Selected Immunological Indices of Carp (Cyprinus carpio L. ) and Silver Carp (Hypophthalmichthys nolitrix Val.). Acta vet. Brno 1998. 67: 265-272.

The aim of this work was to study the effects of Microcystin LR and biomass of blue-green algae with known amount of Microcystin LR on immunological indices in juvenile carp and silver carp.

The pure Microcystin LR or biomass of blue-green algae with a known amount of Microcystin LR was applied to experimental fish. Pure Microcystin LR in the dose of $400 \mu \mathrm{g}$ per $\mathrm{kg}$ of body mass was administered intraperitoneally, the biomass per os to carp and per anus to silver carp. The volume of Microcystin LR in single doses was 3,300,600 and $1200 \mu \mathrm{g}$ per $\mathrm{kg}$ of body mass. After 24 and $48 \mathrm{~h}$ blood was collected from fish by cardiac punction. The following immunological indices were determined: total leukocytes, leukocrit, differential leukocyte count, numbers of sIg+ and $\mathrm{T}$ cytotoxic lymphocytes and occasionally numbers of NK cells by means FITC protein A. HP lectin and monoclonal antibody anti $\mathrm{CD} \mathrm{llb}$ and phagocyte activity by luminol enhanced chemiluminiscence.

Decrease of total leukocyte count and leukocrit were characteristic changes due to the treatment. With carp this decrease occurred mainly in lymphocytes (Tcytotoxic and sIg+ cells), with silver carp mainly in myelocytes (neutrophilic myelocytes and metamyelocytes). With carp the most remarkable changes were observed after oral administration of biomass of blue-green algae containing Microcystin LR in the dose of $1200 \mu \mathrm{g}$ per $\mathrm{kg}$ of body mass. On the other hand, minor changes were observed after i.p. administration of pure toxin. These changes correspond with changes in phagocytic activity of cells: minor changes were detected in carp, while in silver carp the decrease of myelocyte cells brought a major decrease of phagocytic activity.
\end{abstract}

Cyanotoxins, leukocytes, lymphocytes, phagocyte activity

Toxins of blue-green algae (cyanotoxins) are substances of secondary metabolism. They are released into the water during the disintegration of blue-green algae. They are more toxic than toxins of higher plants and fungi and less toxic than bacterial toxins (Maršálek and Turánek 1996).

In human and veterinary medicine cases of health damage or poisoning have been known (Falconer 1989; Carmichael 1992). Cyanotoxins cause an impairment of the immune system, torpidity and complete weakness, vomiting and digestion problems, respiratory and allergic diseases, damage of the liver and other health problems. They also play an important role in process of cancerogenesis (Bell and Codd 1994).

The influence of cyanotoxins on fish following experimental intoxications or the impact of the environment containing cyanotoxins on fish have been studied by a number of authors

\footnotetext{
Address for correspondence:

MVDr. M. Paliková

Department od Game. Fish and Bee Diseases

University of Veterinary and Pharmaceutical Sciences, Palackého 1-3

$612+2$ Bmo. Czech Republic
}

Phone: $++205+1562821$ 
using clinical, pathomorphological, histological, ultrastructural, haematological and biochemical methods (Bruno et al. 1989: Garcia 1989; Råbergh et al. 1991; Johnston et al. 1994; Rodger et al. 1994: Tencalla et al. 1994: Carbis et al. 1996ab: Bury et al. 1997; Navrátil et al. 1997ab).

Immunosuppressive effects of cyanotoxins have been explored and proven e. g. in mice and humans. Mundt et al. (1991) compared the influence of extracts from four various kinds of cyanobacteria and they describe the inhibition of the number of plaque-forming cells in mice after i.p. administration of higher concentrations of toxins. On the other hand, lower concentrations of toxins stimulated the immune system. To our knowledge, there is no data available on the impact of cyanotoxins on the immune system of fish.

The aim of this work was therefore to study the effects of Microcystin LR and biomass of blue-green algae with known amount of Microcystin LR on juvenile carp (Cyprinus carpio L.) and silver carp (Hypophthalmichthys molitrix Val.) immunological indices.

\section{Materials and Methods}

A total of 83 juvenile carp with average mass of $168 \mathrm{~g}(110-380)$ and 44 silver carp with average mass of

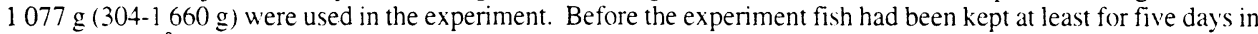
laminated $1 \mathrm{~m}^{3}$ tanks in the water at a temperature of $18^{\circ} \mathrm{C}$ equipped with aeration. Fish were fed a commercial pelleted food for carp. The feeding had been always finished two days before the experiment. The experimental and control groups consisted of 6-8 individuals each. The experiments were finished in 24 and $48 \mathrm{~h}$. For i.p. administration pure Microcy'stin LR (Veterinary Research Institute. Brno, Czech Republic) in the solution of HEPES in the dose $400 \mu \mathrm{g}$ per $\mathrm{kg}$ of body mass was used ( $1 \mathrm{ml}$ containing $100 \mu \mathrm{g}$ of Microcystin LR). For oral. and per anus administration (in silver carp) three kinds of biomass with known amount of Microcystin LR were used. The analysis of biomass was conducted by means of HPLC. Individual doses of biomass were administrated according to the content of Microcystin LR per os to carp in doses 3, 300, 600 and $1200 \mu \mathrm{g}$ per $\mathrm{kg}$ of body mass and per anus to silver carp in doses 3 and $300 \mu \mathrm{g}$ per $\mathrm{kg}$ of body mass. The volume of one-dose biomass was $3.0-3.6 \mathrm{ml}$. For the required volume the biomass was diluted with distilled water. To obtain the total dose of $1200 \mu \mathrm{g}$ of Microcystin LR per $\mathrm{kg}$ of body mass, the biomass was divided into two doses administered in $24 \mathrm{~h}$ intervals. For the experiments with doses 400,600 and $1200 \mu \mathrm{g}$ of Microcystin LR per $\mathrm{kg}$ of body mass the fish were obtained in July (water temperature about $20^{\circ} \mathrm{C}$ ). and for the experiments with doses 3 and $300 \mu \mathrm{g}$ of Microcystin LR per $\mathrm{kg}$ of body mass the fish were obtained in December (water temperature about $8^{\circ} \mathrm{C}$ ). The biomasses dosed in 3 and $300 \mu \mathrm{g}$ of Microcystin LR per $\mathrm{kg}$ of body mass contained besides Microcystin LR also other unidentified substances. Leukocrit. total leukocyte count and differential leukocyte count were evaluated according to Svobodová et al. (1986). Furthermore. the lymphocytes were separated from the blood by discontinual gradient centrifugation and incubated with FITC protein A for the evaluation of numbers of sIg+ lymphocytes (Surolia et al. 1981) and with HP lectin for the evaluation of numbers of cytotoxic lymphocytes (Mattes and Holden 1981: Poros et al. 1983: Kovářu 1987). Further the monoclonal antibody anti CD $11 \mathrm{~b}$ was used. In addition to monocytes and granulocytes. this antibody links to the external antigen of NK cells. It is a rat monoclonal antibody against mouse antigen CD 11b, which reacts in a specific cross way with fish (Palíková et al. 1998). The numbers of cells, HP lectin and protein A were selected on the basis of preceding studies (Palíková et al. 1995). The evaluation was conducted by fluorescence cell sorter - FACS. The evaluation of phagocyte activity by luminol enhanced chemiluminiscence were conducted by the modified method according to $\mathrm{Kubala}$ et al. (1996). Spontaneous and activated chemiluminiscence (CL) by opsonized zymozan were evaluated. Zymozan was opsonized by method according to Leino and Lillius (1992). The kinetics of chemiluminiscence was measured for $77 \mathrm{~min}$ at the temperature of $27{ }^{\circ} \mathrm{C}$ by means of Luminometr 1251 . The measured data included peak of $\mathrm{CL}(\mathrm{mV})$, the time of peak (s) and the integral of $\mathrm{CL}(\mathrm{mV} / \mathrm{s})$. Peak and integral of CL were transferred to 1000 of phagocytes. The statistic evaluation of the data was carried out by help of the hypothesis test of two independent groups ( $T$ - test). The statistic program STAT PLUS 1.01 was used for the evaluation.

\section{Results}

The results of our study are presented in Tables 1 through 4 .

Minor or major decrease of total leukocyte counts (Table 1) and leukocrit were characteristic for changes in white blood cells (leukocrit corresponded with total 
Table 1

Total leukocytes and absolute numbers of lymphocytes in $1 \mu \mathrm{l.10}{ }^{3}$

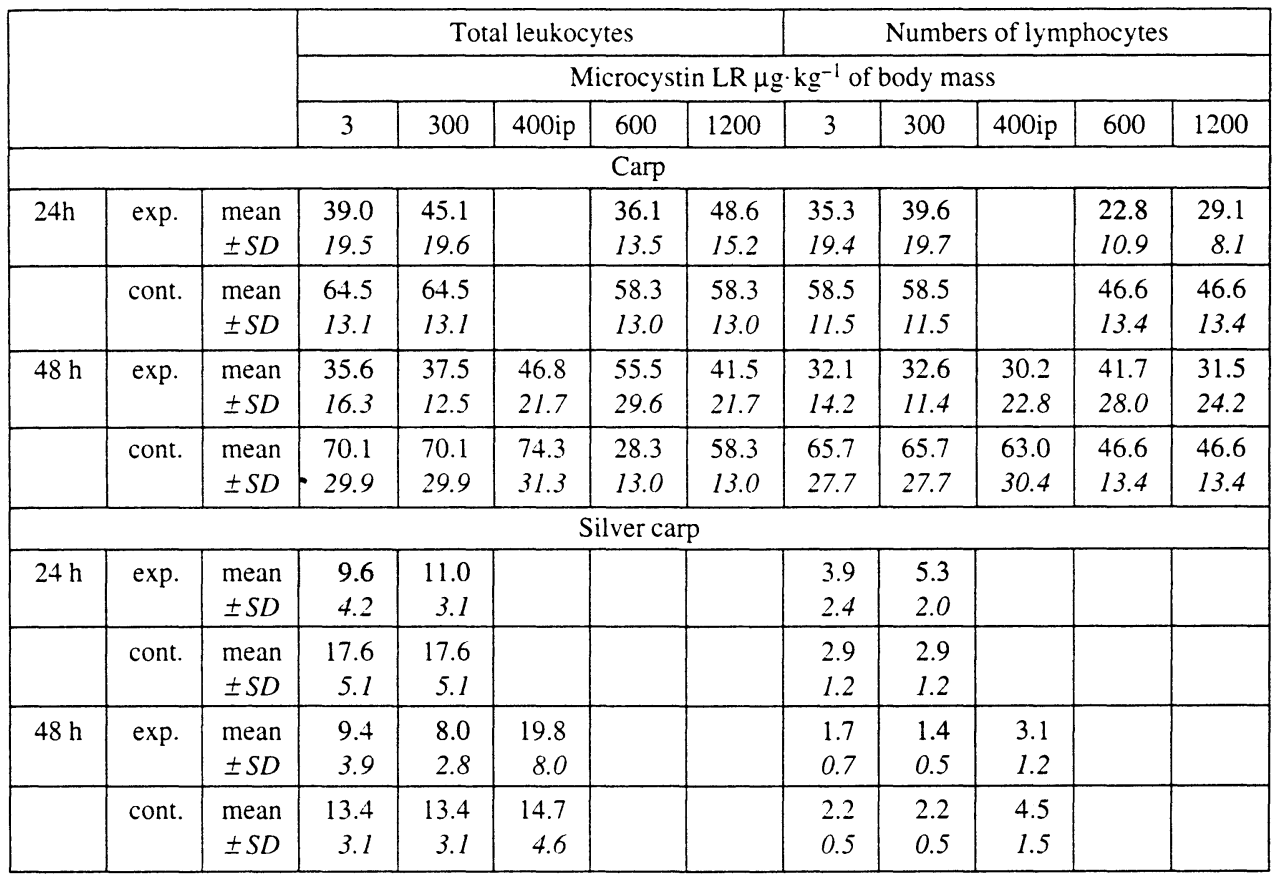

$\mathrm{p} \leq 0.01$

$\mathrm{p} \leq 0.05$

leukocytes). With carp this decrease was affected mainly in lymphocytes (T cytotoxic and sIg+ lymphocytes -Tables 1 and 2), with silver carp mainly in myelocytes (neutrophilic myelocytes and metamyelocytes - Table 4). With carp major changes have been observed following per os administration of biomass of blue-green algae containing Microcystin LR in the dose of $1200 \mu \mathrm{g}$ per $\mathrm{kg}$ of body mass. On the other hand, minor changes have been observed following i.p. administration of pure toxin. These changes correspond with changes in phagocyte activity of cells: minor changes in carp, while in silver carp the decrease of myelocyte cells brought a major decrease of phagocyte activity (Table 3 ).

\section{Discussion}

From the results stated above it is obvious that the influence of water bloom of blue-green algae on fish is dependent not only on the amount of Microcystin LR in biomass but also on other unidentified substances present in biomass of blue-green algae (this is why biomass containing only $3 \mu \mathrm{g}$ of Microcystin LR per $\mathrm{kg}$ of body mass had a similar effect as biomass containing higher amount of this toxin). Further it may be concluded that Microcystin LR alone damages mainly hepatopancreas and affects red blood cells, while the immune system is being influenced by other substances of biomass whose effect can be multiplied by their interaction. Certain differences are in the influence of biomass of blue-green algae to 
Table 2

Absolute numbers of sIg+ and T cytotoxic lymphocytes in $1 \mu \mathrm{l} .10^{3}$

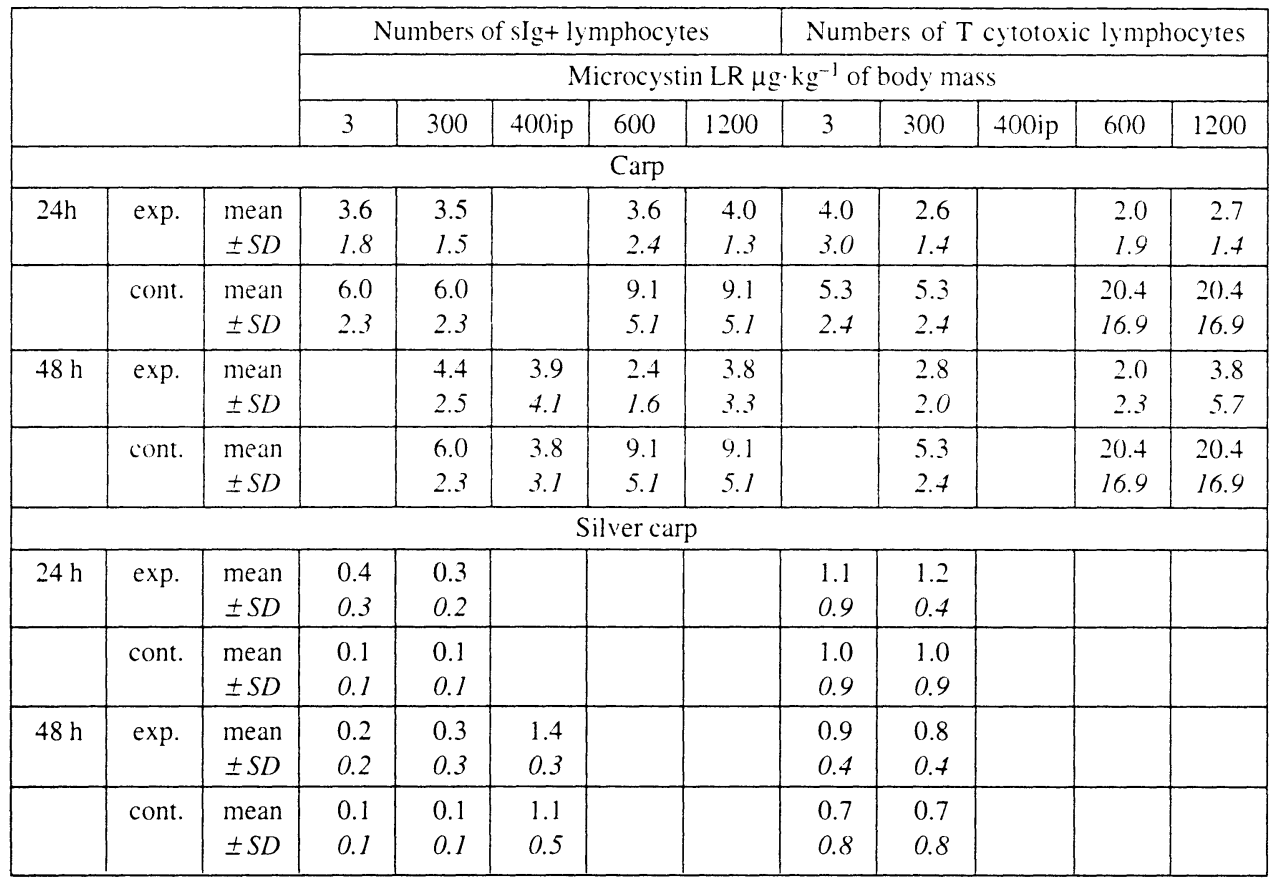

$p \leq 0.01$
$p \leq 0.05$

immune parameters in carp and in silver carp. The decrease of lymphocytes affected both species. These data correspond with data quoted in studies by Navrátil et al. (1997ab), Vajcová et al. (1997). While in carp leukocytes are decreased in lymphocytes, in silver carp the decrease affects especially myelocytes, while on the other hand lymphocytes seem to be stimulated. In lymphocytes of carp was the effect concentrated to specific immune response of cellular and humoral type. The greatest differences have been found in $\mathrm{T}$ cytotoxic lymphocytes which represent the most significant group of cytotoxic cells, which are part of specific cellular immunity (Šterzl 1993). Also specific humoral response has been affected which was reflected in the decrease of $\mathrm{sIg}+$ lymphocytes. These results correspond to a certain extend with the results obtained in mammals (Mundt et al. 1991). This study has shown an immunosuppressive effect in specific immune response. Most likely in the immune area the effect of toxin in fish will be similar to that in mammals. However, this is just a rough comparison, because these authors used different methods for the finding out of immunosuppressive effects of cyanotoxins. Nevertheles in silver carp it has to be said that leukocrit and total leukocyte count were 3-5 times lower and i.e. in control groups. This fact might have been caused by a later catch of silver carp (water temperature about $8{ }^{\circ} \mathrm{C}$ ) and seasonal dynamics in the amount of leukocytes connected with it. Also differential leukocyte counts of silver carp are of different character. After transferring differentional leukocyte counts into absolute numbers and comparing them with numbers of cells in carp it is shown that myelocyte cells are in a certain surplus while on the other hand the number of lymphocytes is drastically reduced. However, the question still remains whether this nonphysiological relationship is caused by stress or whether the relationship in 
Table 3

The peak of chemiluminiscence of transferred phagocyte activity in $\mathrm{m}$. $\mathrm{V}$

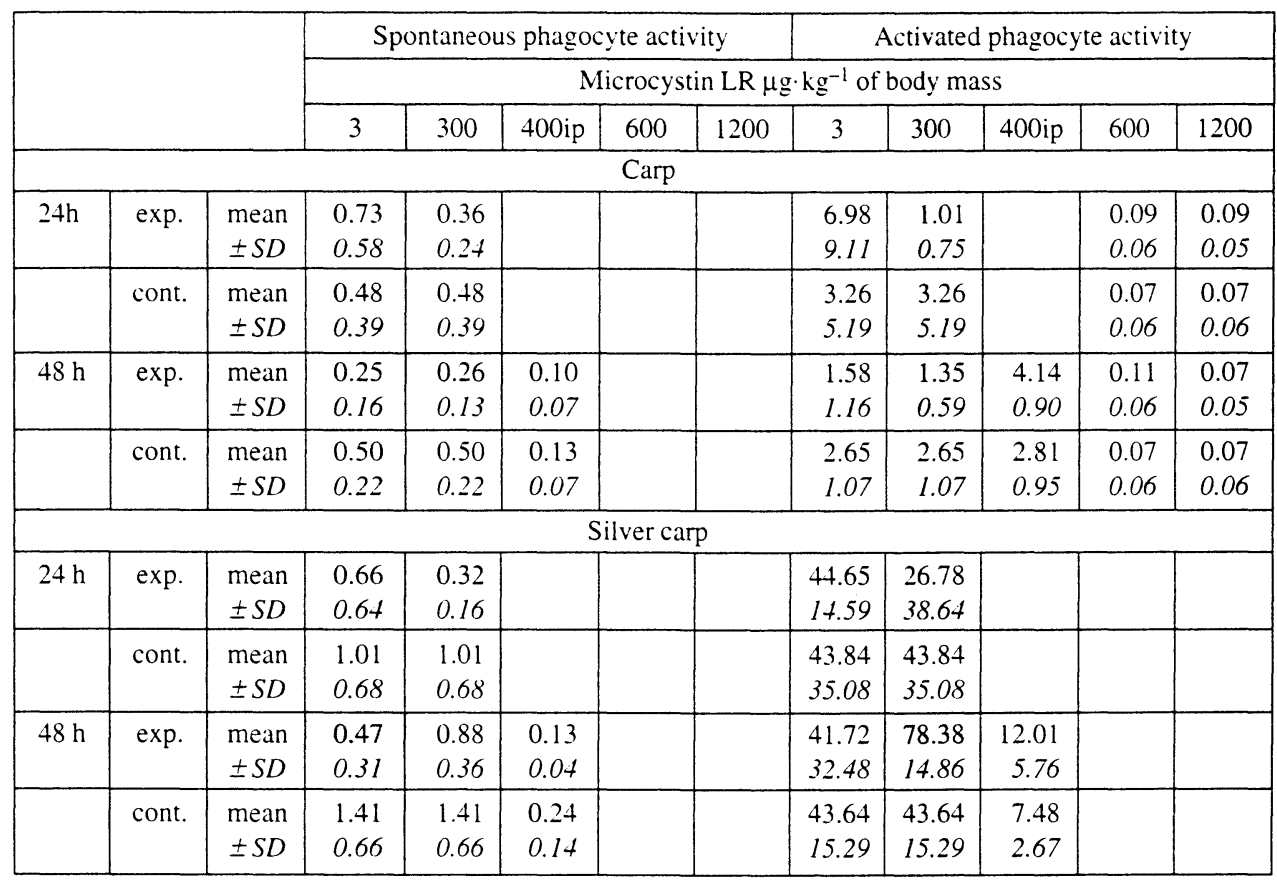

$$
\begin{aligned}
& \mathrm{p} \leq 0.01 \\
& \mathrm{p} \leq 0.05
\end{aligned}
$$

the winter season life in cold water in these fish brings about a decrease in the number of lymphocytes. The third variant could be a combination of both proceding variants. A certain difference can be noted in phagocyte activity of leukocytes. While in carp minor changes occurred more in the sense of decreasing of chemiluminiscence after $48 \mathrm{~h}$, in silver carp major changes occurred already after $24 \mathrm{~h}$, and after $48 \mathrm{~h}$ a certain increase related only to application of dose $300 \mu \mathrm{g}$ of Microcystin LR per $\mathrm{kg}$ of body mass in biomass. These results in silver carp are most likely caused by a higher representation of more mature forms of neutrophilic granulocytes i.e. by a higher potential for releasing loose radicals after stimulation.

\section{Vliv čistého microcystinu LR a biomasy sinic na vybrané imunologické ukazatele kapra (Cyprinus carpio L.) a tolstolobika (Hypophthalmichthys molitrix Val.)}

Cílem práce bylo zjistit vliv microcystinu LR a biomasy sinic se známým obsahem microcystinu LR na imunologické ukazatele násady kapra obecného a tolstolobika bílého.

Pokusným rybám byl aplikován čistý microcystin LR nebo biomasa sinic se známým obsahem microcystinu LR. Aplikace čistého microcystinu LR v dávce $400 \mu \mathrm{g} \cdot \mathrm{kg}^{-1} \breve{z}$. hm. byla prováděna intraperitoneálně, biomasa byla aplikována kaprům perorálně a tolstolobikům peranálně. Obsah microcystinu LR v jednotlivých dávkách byl 3, 300, 600 a $1200 \mu \mathrm{g} \cdot \mathrm{kg}^{-1}$ ž. hm. Po 24 a 48 hodinách po aplikaci byla rybám odebrána krev. Byl stanovován počet leukocytů, leukokrit, diferenciální rozpočet, počet sIg+ lymfocytů 
Table 4

Differential leukocyte counts of fish after application of 3 and $300 \mu \mathrm{g}$ of Microcystin LR in biomass per $1 \mathrm{~kg}$ of body mass

\begin{tabular}{|c|c|c|c|}
\hline Carp & $3 \mu \mathrm{g}$ & $300 \mu g$ & Control \\
\hline After $24 \mathrm{~h}$ & \multicolumn{3}{|c|}{ Mean $\pm S D(\%)$} \\
\hline Blasts (mono-. myelo-, lympho-) & $1.19 \pm 0.86$ & $0.94 \pm 0.98$ & $0.69 \pm 0.83$ \\
\hline Monocytes & $0.63 \pm 0.65$ & $1.63 \pm 0.86$ & $1.13 \pm 0.54$ \\
\hline Neutrophilic myelocytes & $2.06 \pm 1.63$ & $1.88 \pm 0.96$ & $1.56 \pm 1.38$ \\
\hline Neutrophilic metamyelocytes & $4.50 \pm 5.45$ & $5.44 \pm 3.46$ & $3.31 \pm 1.60$ \\
\hline Band neutrophil & $2.88 \pm 2.12$ & $2.38 \pm 1.45$ & $1.38 \pm 1.17$ \\
\hline Segmenter neutrophil & $0.94 \pm 0.13$ & $1.50 \pm 1.54$ & $0.94 \pm 0.95$ \\
\hline Lymphocytes & $87.75 \pm 9.96$ & $86.85 \pm 4.92$ & $91.00 \pm 2.37$ \\
\hline \multicolumn{4}{|l|}{ After $48 \mathrm{~h}$} \\
\hline Blasts (mono-, myelo-. lympho-) & $0.81 \pm 0.83$ & $1.63 \pm 1.71$ & $0.44 \pm 0.46$ \\
\hline Monocytes & $2.63 \pm 1.76$ & $1.38 \pm 0.65$ & $1.38 \pm 0.84$ \\
\hline Neutrophilic myelocytes & $3.63 \pm 1.90$ & $3.50 \pm 2.65$ & $1.69 \pm 1.90$ \\
\hline Neutrophilic metamyelocytes & $11.88 \pm 1.54$ & $4.44 \pm 3.37$ & $1.81 \pm 1.39$ \\
\hline Band neutrophil & $0.88 \pm 0.33$ & $0.88 \pm 0.93$ & $0.81 \pm 0.86$ \\
\hline Segmenter neutrophil & $0.19 \pm 0.24$ & $0.88 \pm 0.82$ & $0.63 \pm 0.41$ \\
\hline Lymphocytes & $90.00 \pm 3.94$ & $87.13 \pm 6.75$ & $93.25 \pm 3.92$ \\
\hline Silver carp & $3 \mu \mathrm{g}$ & $300 \mu \mathrm{g}$ & Control \\
\hline After $24 \mathrm{~h}$ & \multicolumn{3}{|c|}{ Mean $\pm \mathrm{SD}(7)$} \\
\hline Blasts (mono-, myelo-, lympho-) & $0.50 \pm 0.71$ & $0.75 \pm 0.83$ & $0.88 \pm 0.60$ \\
\hline Monocytes & $1.13 \pm 0.93$ & $1.56 \pm 1.26$ & $3.75 \pm 1.85$ \\
\hline Neutrophilic myelocytes & $23.13 \pm 10.82$ & $17.19 \pm 7.86$ & $53.75 \pm 8.69$ \\
\hline Neutrophilic metamyelocytes & $21.50 \pm 4.77$ & $22.50 \pm 11.34$ & $21.13 \pm 6.45$ \\
\hline Band neutrophil & $13.75 \pm 4.35$ & $6.44 \pm 3.42$ & $3.50 \pm 1.87$ \\
\hline Segmenter neutrophil & $0.63 \pm 0.86$ & $0.31 \pm 0.66$ & $0.25 \pm 0.66$ \\
\hline Lymphocytes & $39.38 \pm 12.97$ & $51.25 \pm 18.26$ & $16.75 \pm 6.70$ \\
\hline \multicolumn{4}{|l|}{ After $48 \mathrm{~h}$} \\
\hline Blasts (mono-, myelo-, lympho-) & $2.00 \pm 2.35$ & $4.80 \pm 4.58$ & $2.00 \pm 1.66$ \\
\hline Monocytes & $3.75 \pm 2.22$ & $2.00 \pm 1.10$ & $3.38 \pm 2.29$ \\
\hline Neutrophilic myelocytes & $51.50 \pm 10.23$ & $34.00 \pm 13.61$ & $60.25 \pm 5.47$ \\
\hline Neutrophilic metamyelocytes & $14.25 \pm 5.45$ & $28.20 \pm 6.40$ & $11.63 \pm 4.55$ \\
\hline Band neutrophil & $8.25 \pm 4.89$ & $12.80 \pm 3.66$ & $5.38 \pm 3.94$ \\
\hline Segmenter neutrophil & $0.13 \pm 0.33$ & $0.20 \pm 0.40$ & $0.50 \pm 1.32$ \\
\hline Lymphocytes & $18.88 \pm 9.01$ & $18.00 \pm 4.60$ & $16.88 \pm 3.55$ \\
\hline
\end{tabular}

$$
\begin{aligned}
& p \leq 0.01 \\
& p \leq 0.05
\end{aligned}
$$

a cytotoxických lymfocytů, případně NK buněk pomocí HP lektinu, FITC proteinu A a monoklonální protilátky anti CD 11b a fagocytární aktivita luminolem zesílenou chemiluminiscencí.

Změny $\mathrm{v}$ bílém krevním obraze byly charakterizovány menším či větším snížením celkového počtu leukocytů a leukokritových hodnot. U kaprů toto snížení postihovalo 
zejména oblast lymfocytární (Tcytotoxické a sIg+lymfocyty), u tolstolobiků zejména oblast myelocytární (zejména neutrofilní myelocyty a metamyelocyty). K nejvýraznějším změnám došlo u kaprů po perorální aplikaci biomasy sinic obsahující mikrocystin LR a to v dávce $1200 \mu \mathrm{g} \cdot \mathrm{kg}^{-1}$ ž. hm. Naopak k méně výrazným změnám došlo po intraperitoneální aplikaci čistého toxinu. S těmito změnami korelují i změny ve fagocytární aktivitě buněk. Zatímco u kaprů došlo k méně výrazným změnám, u tolstolobiků došlo v souvislosti se snížením myelocytárních buněk k výraznějšímu snížení fagocytární aktivity.

\section{Acknowledgement}

This work was supported by the Fund of Development of Universities of the Ministry of Education, Youth and Sports of the Czech Republic (Project No. 32/97), by the internal grant of the University of Veterinary and Pharmaceutical Sciences Brno and by the Nadatio Flos - aque.

\section{References}

BELL, S. G., CODD, G. A. 1994: Cyanobacterial toxins and human health. Rew. Medic. Microbiol. 5(4): 256-264 BRUNO, D. W., DEAR, G., SEATON, D. D. 1989: Mortality associated with phytoplankton blooms among farmed Atlantic salmon, Salmo salar, L., in Scotland. Aquaculture 78: 217-222

BURY. N. R., McGEER, J. C.. EDDY, F. B., CODD, G. A. 1997: Liver damage in brown trout, Salmo trutta L., and rainbow trout, Oncorhynchus mykiss (Walbaum), following administration of cyanobacterial hepatotoxin microcystin-LR via the dorsal aorta. J. Fish Diseases 20: 209-215

CARMICHAEL. W. W. 1992: A status report on planctonic cyanobacteria (blue-green algae) and their toxins. Environmental Monitoring Systems Laboratory, Office of Research and Development, U. S. Environmental Protection Agency, Cincinnati, Ohio

CARBIS. C. R., MITCHELL, G. F., ANDERSON, J. W., Mc CAULEY. I. 1996a: The effect of microcystins on the serum biochemistry of carp, Cyprinus carpio, L., when toxins are administered by gavage. immersion and intraperitoneal routes. J. Fish Diseases 19: 151-159

CARBIS. C. R., RAWLIN, G. T., MITChELl, G. F., ANDERSON, J. W., Mc CAULEY, I. 1996b: The histopathology of carp, Cyprinus carpio, L.. exposed to microcystins by gavage, immersion and intraperitoneal administration. J. Fish Diseases 19: 199-207

FALCONER, R.. I.1989: Effects on human health of some toxic cyanobacteria. Toxic. Assess. 4: 175-184

GARCIA. B. O. 1989: Toxicity of the cyanobacterium. Microcystis aeruginosa strain 7820 to trout and tilapia: a clinical and histopathological study. M. Sc. Thesis, University of Stirling

JOHNSTON, N. A. L., CAMPAGNA. V. S.. HAWKINS. P. R., BANENS. R. J. 1994: Response of the eastern rainbowfish (Melanotaenia duboulayi) to toxic Microcystis aeruginosa. Aust. J. Mar. Freshwater Res.: 917-923

KOVÁR̆Ů, F. 1987: Immunological characteristics of pig ontogenetic model. Thesis MBU ĆSAV Praha, Vols 1 and $2.507 \mathrm{pp}$.

KUBALA. L., LOJEK. A., Číž. M., VONDRÁČEK. J., DUŠKOVÁ, M., SLAVIKOVÁ, H. 1996: Stanovení

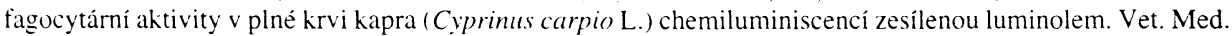
- Czech 41: 323-327

LEINO. L., LILLIUS. E. M., 1992: The up- and down-modulation of immunoglobulin G Fe receptors and complement receptors an activated human neutrophils depends on mature of activator. J. Leuk. Biol. 51: 157-163

MARŚÁLEK. B., TURÁNEK. J. 1996: Biologicky aktivní látky produkované sinicemi vodniho květu. In: Vodní květy sinic. ED.: MARŚÁLEK - KERŠNER - MARVAN, Nadatio flos-aquae. Brno, pp. 86-100

MATTES de, M.. J.. HOLDEN, H. T. 1981: The distribution of Helix pomatia lectin receptors on mouse lymfoid cells and other tissues. Eur. J. Immunol. 11: 358

MUNDT. S., EFFMERT. U., GRANITZKA. V., NOVOTNY. A., TEUSCHER. E. 1991: Immunosupressive substances from blue-green algae. Agents and Actions 32(1/2): 117-118

NAVRÁTIL. S., PALÍKOVÁ. M., VAJCOVÁ. V.. TICHÝ. F.. ŠTÉRBA. F., MARŚSÁLEK. B., NEČA. J. 1997a: Vliv toxinů sinic na kapra po perorální aplikaci. Sborník referátủ konference Toxicita a biodegradabilita odpadů a látek významných ve vodním prostředi. Chelčice. (Ed. VÚRH JU), 1997: $116-120$

NAVRÁTIL. S., PÁLÍKOVÁ, M., VAJCOVÁ. V., TICHÝ. F., ŚTÉRBA. F., MARŚÁLEK. B.. NEĆA. J. 1997b: Současné vědomosti o působení cyanotoxinů na ryby. Sborník referátů konference Ochrana zdraví ryb. Vodňany. (Ed. VÚRH JU). 1997: 166-171

PALÍKOVÁ. M.. KOVÁŔ I. F., NAVRÁTIL. S. 1995: The use of lectins and FIT C protein A for the differentiation of populations and subpopulations $T$ and $B$ lymphocytes in fish. Book of papers of The $4^{\text {th }}$ Ichtyohaematology conference. Hluboká nad Vltavou, (Ed. VÜRH JU), 1998: 75-80 
PALÍKOVÁ, M., KOVÁR̃Ũ, F., PEŠÁK, S., NAVRÁTIL, S. 1998: Possibilities for phenotypisation of lymphocytes in fish. Book of abstracts of The $4^{\text {th }}$ Nordic Symposium on Fish Immunology, Hirtshals, Denmark, (Ed. by The Nordic Society for Fish Immunology), 1998: Bp7

POROS, A., AHRLUND, RICHTER, L., KLEIN, E., HAMMARSTRON, S., KOIDE, N. 1983: Expression of Helix pomatia haemaglutinin receptors on cytolytic receptors activated in mixed cultures. J. Immunol. Meth. 57: 9

RÅBERGH, C., M., I., BYLUND, G., ERIKSSON, J. E. 1991: Histopathological effects of microcystin LR, a cyclic peptide toxin from the cyanobacterium (blue-green alga) Microcystis aeruginosa on common carp (Cyprinus carpio L.). Aquatic Toxicology 20: 131-146

RODGER, H. D., TURNBULL. T., EDWARDS. C, CODD, G. A. 1994: Cyanobacterial (blue-green algal) bloom associated pathology in brown trout, Salmo trutta L., in Loch Leven, Scotland. J. Fish Diseases 17: 177-181

SUROLIA. A. et al. 1981:Trends Bioch. Sci. 7: 74

SVOBODOVÁ, Z., PRAVDA, D.. PALÁĆKOVÁ, J. 1986: Jednotné metody hematologického vyšetřování ryb. Edice metodik VÚRH ve Vodňanech, Vodňany, $36 \mathrm{p}$.

STERZL, J. 1993: Imunitní systém a jeho fyziologické funkce. Česká imunologická společnost Praha, 480 p.

TENCALLA. F. G., DIETRICH. D. R., SCHLATTER, CH. 1994: Toxicity of Microcystis aeruginosa peptide toxin to yearling rainbow trout (Oncorhynchus mykiss). Aquat. Tox. 30: 215-224

VAJCOVÁ. V.. NAVRÁTIL, S.. PALÍKOVÁ, M. 1997: Vliv toxinů produkovaných sinicemi na zdravotní stav násady tolstolobika bílého (Hypopthalmichthys molitrix Val.). Sborník referátů konference Ochrana zdraví ryb. Vodñany. (Ed. VÚRH JU), 1997: 179-184 